\title{
$\mathrm{AlN}$ 기계적 성질에 미치는 $\mathrm{BN}$ 첨가 영향
}

\author{
조우진 ${ }^{1} \cdot$ 오세훈 ${ }^{2}$ · 손인진 ${ }^{1, *}$ \\ 1전북대학교 신소재공학부 수소연료전지 연구센터 \\ 2중앙대학교 기계공학과
}

\section{Effect of BN Addition on the Mechanical Properties of AIN}

\author{
Woo-Jin Cho' ${ }^{1}$, Se-Hoon $\mathrm{Oh}^{2}$, and In-Jin Shon ${ }^{1, *}$ \\ ${ }^{1}$ Division of Advanced Materials Engineering, Research Center of Hydrogen Fuel Cell, Chonbuk National University, \\ Jeonju 54896, Republic of Korea \\ 2Department of Mechanical Engineering, Chung-Ang University, Seoul 06974, Republic of Korea
}

\begin{abstract}
Aluminum nitride (AlN) has several attractive properties including high thermal conductivity, excellent electrical insulation, a thermal expansion coefficient close to that of $\mathrm{Si}$ and low density. Accordingly, it is considered a promising packing material and substrate for high power integrated circuits. However, its low fracture toughness at room temperature limits its wide industrial application. To improve its mechanical properties, the approach generally utilized has been to fabricate and add nanostructured materials as a second phase, to make composites. In this study highly dense nanostructured AlN and AlN$\mathrm{BN}$ composites were sintered for two minutes at $1400{ }^{\circ} \mathrm{C}$. The effect of $\mathrm{BN}$ on the mechanical properties (fracture toughness and hardness) and the microstructure of the AlN-BN composites was investigated. The hardness and fracture toughness of AlN, AlN-1 vol\% BN, AlN-3 vol\% BN, AlN-10 vol\% BN were 943, 1455, $1147,1110 \mathrm{~kg} / \mathrm{mm}^{2}$ and 4, 5.7, 5.5, $5.4 \mathrm{MPa} \cdot \mathrm{m}^{1 / 2}$, respectively. The addition of BN to AlN simultaneously improved the hardness and fracture toughness of the AlN-BN composite by deterring crack propagation. This study demonstrates that $\mathrm{BN}$ can be an effective reinforcing material to improve the fracture toughness and hardness of AlN composites.
\end{abstract}

(Received January 7, 2019; Accepted January 31, 2019)

Keywords: nanomaterials, sintering, composite, mechanical properties

\section{1. 서 론}

$\mathrm{AlN}$ 은 우수한 절연성, 높은 열전도도, 낮은 밀도, $\mathrm{Si}$ 과 비슷한 열팽창 계수를 가지고 있기 때문에 고 전력 집적 회로 기판에 사용할 수 있는 유망한 재료로 알려져 있다. 하지만 $\mathrm{AlN}$ 의 파괴인성은 다른 세라믹재료와 같이 연성취성 천이온도 이하에서 나쁜 단점이 있다 [1]. 공업적으로 폭 넓게 사용하기 위해서는 파괴 인성을 향상시켜야 한다. 재료의 경도와 동시에 파괴인성을 향상시키기 위해서는 일 반적으로 제 2상을 첨가해서 나노구조의 복합재료를 제조 하는 것이다 [2,3]. 복합재료에서 제 2 상은 균열 가교 와

- 조우진: 석사과정, 오세훈·손인진 : 교수

*Corresponding Author: In-Jin Shon

[Tel: +82-63-270-2381, E-mail: ijshon@chonbuk.ac.kr]

Copyright (C) The Korean Institute of Metals and Materials
균열 굴절에 의해 균열 전파를 억제시키는 것으로 보고되 고 있다. 나노구조는 재료의 파괴 인성과 경도를 향상시키 기 때문에 많은 연구자들이 나노재료에 대해 연구를 하고 있다 $[4,5]$.

$\mathrm{AlN}$ 은 강한 공유결합을 하고 있고, 구성 원소의 확산 계 수가 낮기 때문에 소결이 어렵다. 고밀도의 $\mathrm{AIN}$ 제조는 소결조제를 첨가해서 $1800{ }^{\circ} \mathrm{C}$ 이상의 온도로 가열해서 만 들고 있다 [6-8]. 소결온도가 높아서 소결도중에 입 성장이 일어나서 나노구조의 $\mathrm{AIN}$ 을 제조하기 어렵다. 소결온도를 낮추는 방법은 다음과 같이 생각할 수 있다. 첫번째는 분 말을 고에너지 볼밀링으로 분말을 미세화시키고 분말에 결 함과 스트레인을 발생시켜서 소결에 대한 구동력을 증가시 키고 반응 장소를 증가시킨다 [9-11]. 두번째는 분말에 펄 스된 고 전류를 흘려주어서 플라즈마 발생으로 표면 정화 
와 전기장하에서는 전자의 이동에 의한 원자의 확산이 빠 르기 때문에 소결온도를 낮출 수 있다 [12,13]. 소결중 결 정립 성장을 억제시키는 방법은 소결 온도를 낮추는 방법 과 반응하지 않는 제 2상을 첨가하는 방법이 있다. 첨가하 는 제 2상으로는 $\mathrm{BN}$ 을 생각할 수 있다. $\mathrm{BN}$ 은 그래핀과 특성이 비슷하기 때문에 백색 그래핀으로 불리고 있으며 이빈 외 4 인의 연구에 따르면 [14]은 최근에 $\mathrm{Si}_{3} \mathrm{~N}_{4}$ 에 $\mathrm{BN}$ 을 첨가해서 파괴인성을 향상시켰다.

본 연구에서는 $\mathrm{AlN}$ 과 $\mathrm{BN}$ 분말을 고 에너지 볼 밀링으 로 혼합과 동시에 나노분말을 제조한다. 제조한 나노분말 들을 펄스전류 활성 소결장치로 가열하여 짧은 시간에 $\mathrm{AlN}$ 과 AlN-BN 나노 복합재료를 제조하고자 한다. 제조한 재료의 미세조직과 기계적 성질 (파괴 인성, 경도)을 평가 한 후, 미세조직과 기계적 성질에 미치는 $\mathrm{BN}$ 의 영향을 고 찰 분석하고자 한다.

\section{2. 실험방법}

본 연구에서 사용한 AlN은 미국 Alfa 회사에서 구입하 였고, 분말의 크기는 $4 \mu \mathrm{m}$ 이하이며 순도는 $99.5 \%$ 이었다. $\mathrm{BN}$ 은 일본 Denka (grade GP)에서 구입하였고, 분말의 크 기는 $8 \mu \mathrm{m}$ 이하였다. $\mathrm{AlN}, \mathrm{AlN}-1 \mathrm{vol} \% \mathrm{BN}, \mathrm{AlN}-3$ $\mathrm{vol} \% \mathrm{BN}, \mathrm{AlN}-10 \mathrm{vol} \% \mathrm{BN}$ 조성에 맞도록 $\mathrm{AlN}$ 과 $\mathrm{BN}$ 분말 무게를 계산한 후 측량하였다. 측량한 분말들을 아르 곤 분위기하에서 스테인레스 용기에 넣고 $250 \mathrm{rpm}$ 으로 10 시간 동안 직경이 $8 \mathrm{~mm}$ 인 $\mathrm{WC}-\mathrm{Co}$ 초경 볼로 고 에너지 밀링하였다. 밀링한 분말들은 흑연 다이에 충진하였다. 펄 스전류 활성 소결 장치의 개략도는 참고문헌 [15]에 나타 내었다. 펄스전류 활성 소결장치 내부를 진공분위기로 만 든 후, 분말에 $80 \mathrm{MPa}$ 의 압력을 가하였다. 그 후 2,000 $\mathrm{A}$ 의 펄스 전류를 흑연 다이와 분말에 $1,400{ }^{\circ} \mathrm{C}$ 에 도달할 때까지 가하였다. 이때 가열 속도는 약 $1,300^{\circ} \mathrm{C} / \mathrm{min}$ 로 2 분이내에 소결이 완료되었다.

소결한 AlN과 AlN-BN 시편의 상대밀도는 시편의 부피 를 아르키메데스 방법으로 측정한 후 밀도를 계산하여 평 가하였다. 소결한 시편들은 알루미나 분말과 다이아몬드 페 이스트를 사용하여 시편을 경면 연마하였다. 시편의 결정 상은 $\mathrm{Cu}$ 타겟을 사용하여 $\mathrm{X}$-선 회절 도형 분석으로 결정 하였다. 미세조직과 조성은 $\mathrm{EDS}$ 가 부착된 주사전자현미경 으로 관찰 및 분석하였다. 밀링한 분말과 소결한 시편의 결정자 크기는 X-선 회절피크의 반가폭을 이용하여 Suryanarayana 식을 사용하여 계산하였다 [16]. AlN와 AlN-BN 복합재료의 경도는 경면 연마된 시편을 비커스
경도계로 $20 \mathrm{kgf}$ 하중으로 15 초간 유지하여 압흔을 형성 시킨 후, 형성된 압흔의 면적과 하중으로부터 경도를 계산 하였다. 파괴인성은 압흔의 모서리에서 전파된 균열의 길 이를 측정하여 Niihara 식으로 계산하였다 [17].

\section{3. 결과 및 고찰}

그림 1 은 초기분말 $\mathrm{AlN}$ 과 $\mathrm{BN}$ 의 $\mathrm{X}$-선 회절 패턴를 나 타낸 것이다. 그림 1 (a)에서는 모든피크가 AlN이었고, 그 림 1 (b)에서는 모든 피크가 $\mathrm{BN}$ 이었다. 10시간 동안 볼 밀링한 AlN-BN분말의 X-선 회절 패턴은 그림 2에 나타 내었다. 그림 2에서 반가폭은 초기분말의 반가폭 보다 컸 다. 이것은 볼밀링 도중에 분말이 미세화 되었고, 분말에 스트레인이 도입되었기 때문으로 판단된다. 그림 3 은 입자 의 크기를 Suryanarayana 식[16]으로 구하기 위해서 $\operatorname{Sin} \theta$ 에 따른 $\mathrm{Br} \operatorname{Cos} \theta$ 값을 나타낸 것이다. $\mathrm{AlN}, \mathrm{AlN}-1$ vol\%
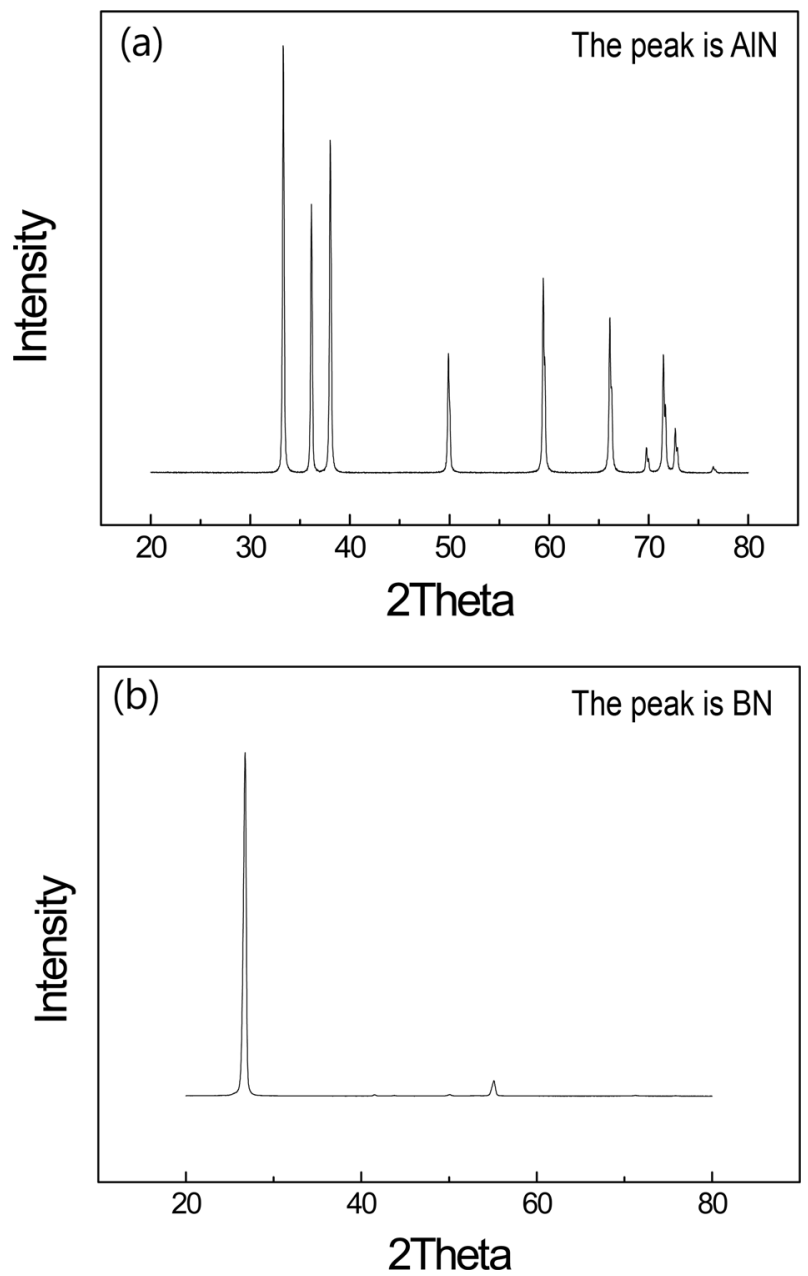

Fig. 1. XRD patterns of the raw powder : (a) AIN, (b) BN. 


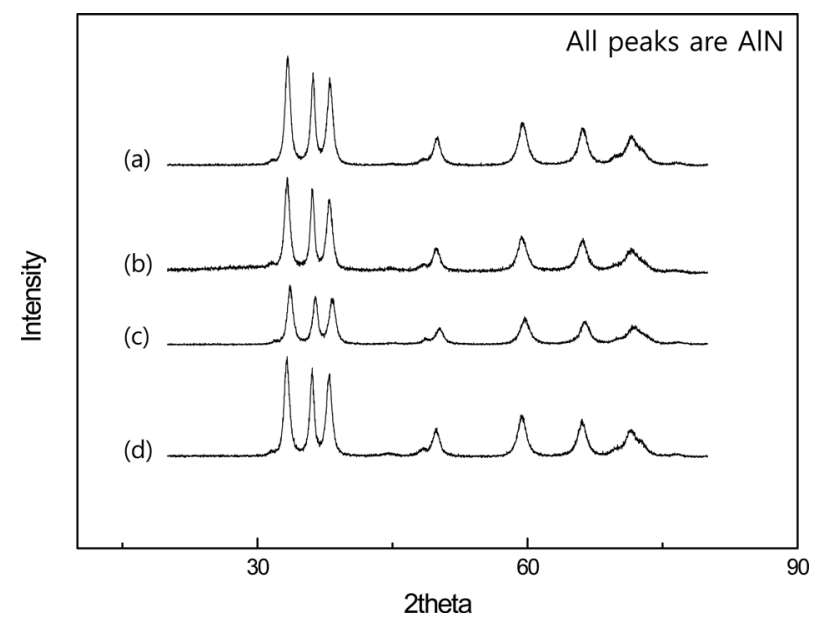

Fig. 2. XRD patterns of the AIN $+x$ vol $\% \mathrm{BN}$ powder milled for $10 \mathrm{~h}$ : (a) $\mathrm{x}=0,(\mathrm{~b}) \mathrm{x}=1,(\mathrm{c}) \mathrm{x}=3,(\mathrm{~d}) \mathrm{x}=10$.

$\mathrm{BN}, \mathrm{AlN}-3 \mathrm{vol} \% \mathrm{BN}, \mathrm{Al}-10 \mathrm{vol} \% \mathrm{BN}$ 분말에서 $\mathrm{AlN}$ 분말의 크기는 각각 $20,23,18,18 \mathrm{~nm}$ 이었다. $\mathrm{AlN}-10$ vol\% $\mathrm{BN}$ 분말을 10 시간 고 에너지 볼 밀링한 분말의 주
사전자현미경 조직과 $\mathrm{EDS}$ 분석결과는 그림 4 에 나타내었 다. 밀링한 분말은 매우 미세하고, 분말들이 응집되어 있음 을 알 수 있다. 밀링한 $\mathrm{AlN}-10 \mathrm{vol} \% \mathrm{BN}$ 혼합 분말의 $\mathrm{EDS}$ 분석에서는 $\mathrm{Al}, \mathrm{N}, \mathrm{B}$ 과 $\mathrm{Pt}$ 피크만 관찰되었고, 볼이 나 용기로부터 오염될 수 있는 텅스텐 이나 철 피크는 관 찰되지 않았다. $\mathrm{Pt}$ 피크는 분말의 미세조직을 선명하게 관 찰하기 위해서 분말을 $\mathrm{Pt}$ 로 코팅하였기 때문에 관찰된 것 이다. 밀링한 $\mathrm{AlN}$ 과 $\mathrm{AlN}-\mathrm{BN}$ 분말에 $80 \mathrm{MPa}$ 의 기계적 압력과 $2000 \mathrm{~A}$ 의 펄스 전류를 분말에 가해서 $1400{ }^{\circ} \mathrm{C}$ 에 서 2 분 이내에 소결하였다. 그림 5 는 $1400{ }^{\circ} \mathrm{C}$ 로 가열한 시편의 $\mathrm{X}$-선 회절 패턴을 나타낸 것이다. $\mathrm{X}$-선 회절패턴 에서는 $\mathrm{AlN}$ 피크만 관찰되었다. $1400{ }^{\circ} \mathrm{C}$ 로 소결한 $\mathrm{AlN}$ 과 AlN-BN 시편에서, AlN 결정립 크기를 Suryanarayana 식 [16]으로 평가하기 위해서 $\operatorname{Sin} \theta$ 에 따른 $\operatorname{Br} \operatorname{Cos} \theta$ 값을 도 시한 것은 그림 6에 나타내었다. 절편의 값으로부터 계산 한 AlN, AlN-1 vol\% BN, AlN-3 vol\% BN, AlN-10 $\mathrm{vol} \% \mathrm{BN}$ 에서 $\mathrm{AlN}$ 결정립 크기는 각각 $220,207,200$, $173 \mathrm{~nm}$ 이었다. 이것은 $\mathrm{AlN}$ 결정립 크기가 $\mathrm{BN}$ 첨가에 따 라 감소함을 의미한다. $\mathrm{BN}$ 이 소결도중에 $\mathrm{AlN}$ 의 성장을
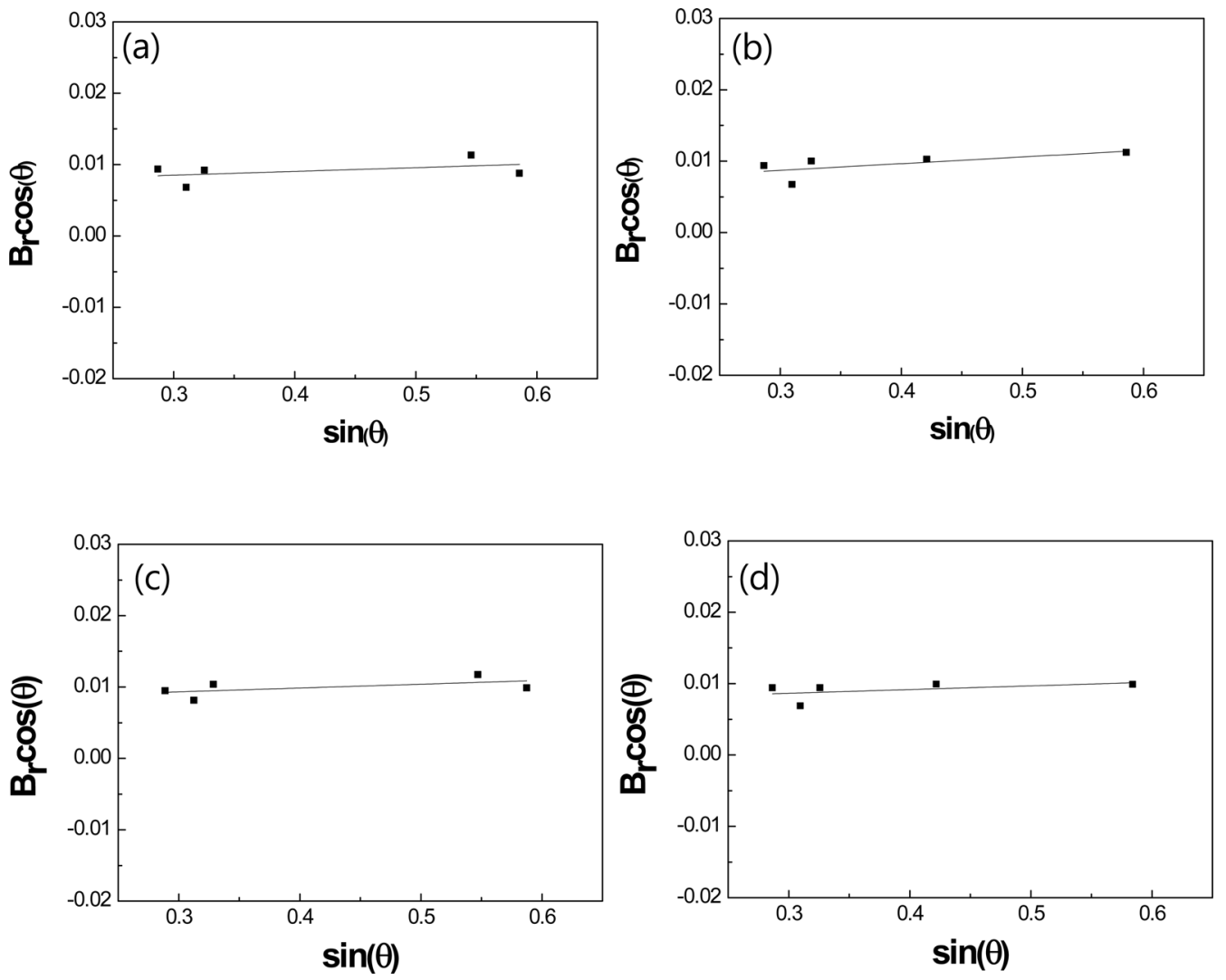

Fig. 3. Plot of $B r\left(B_{\text {crystalline }}+B_{\text {strain }}\right) \cos \theta$ versus $\sin \theta$ for $A I N$ in $A I N+x$ vol\% BN powders milled for $10 h$ : (a) $x=0$, (b) $x=1$, (c) $x=3$, (d) $\mathrm{x}=10$. 

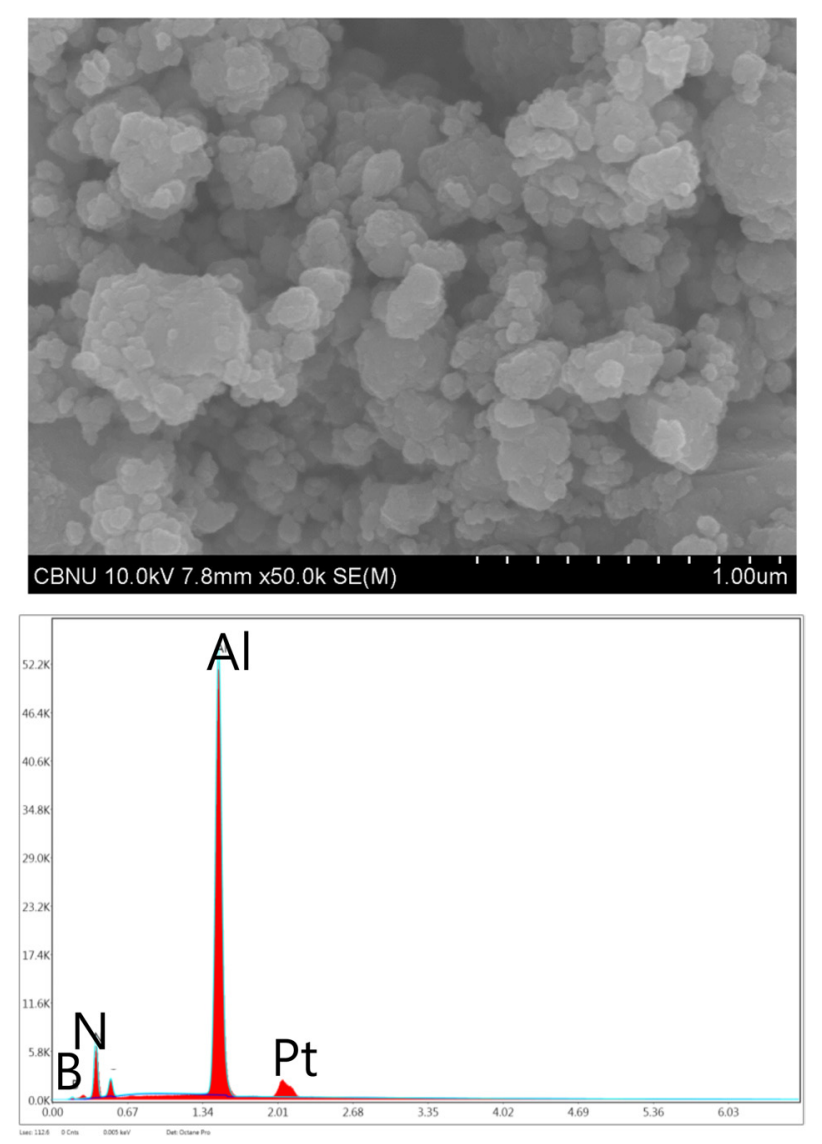

Fig. 4. FE-SEM image and EDS of AIN powder +10 vol\% BN powder milled for $10 \mathrm{~h}$.

억제시킨다고 생각된다. $\mathrm{BN}$ 이 결정립 미세화에 미치는 영 향은 미세조직에서도 관찰할 수 있다. 그림 7 은 $1400{ }^{\circ} \mathrm{C}$ 로 소결한 시편 파단면을 주사전자현미경으로 관찰한 미세 조직을 나타낸 것이다. $\mathrm{AlN}$ 결정립 크기는 $\mathrm{BN}$ 첨가로 감 소함을 관찰할 수 있다. $\mathrm{BN}$ 을 첨가하지 않은 순수한 $\mathrm{AlN}$ 미세조직에서도 결정립이 미세함을 알 수 있다. 이것은 가 열속도가 빠르고, 가열시간이 짧아서 시편이 고온에 가열 될 시간이 작아서 $\mathrm{AlN}$ 결정립 성장이 어렵기 때문으로 판 단된다. 또한, 고 에너지 볼 밀링한 $\mathrm{AIN}$ 나노분말을 초기 분말로 사용했기 때문으로 생각된다. 고 에너지 볼 밀링한 분말은 분말에 도입된 결함과 스트레인 증가로 소결에 대 한 구동력이 크고, 원자들이 상호 확산할 수 있는 분말 접 촉점들의 증가로 소결이 저온에서 이루어지기 때문으로 생 각된다. $1400{ }^{\circ} \mathrm{C}$ 로 소결한 $\mathrm{AlN}, \mathrm{AlN}-1 \mathrm{vol} \% \mathrm{BN}, \mathrm{AlN}-$ $3 \mathrm{vol} \% \mathrm{BN}, \mathrm{AlN}-10 \mathrm{vol} \% \mathrm{BN}$ 시편의 상대밀도는 각각 $98,100,98$ 과 $98 \%$ 이었다. 모든 시편의 파단면에서는 균 열이 결정립계를 따라서 전파하는 입계 파괴 현상을 주로 보이고 있다. 이것은 결정립계의 원자간 결합이 결정립내

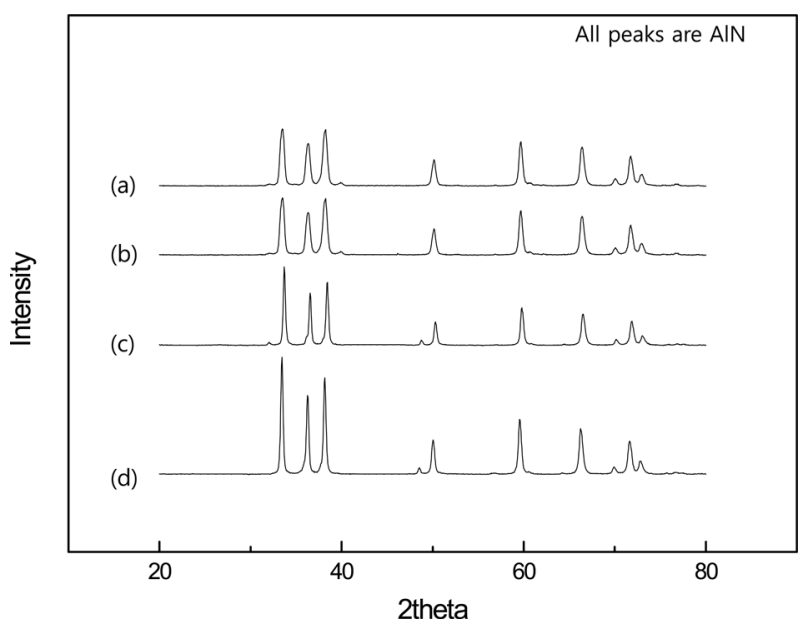

Fig. 5. XRD patterns of $\mathrm{AlN}+\mathrm{x}$ vol $\% \mathrm{BN}$ samples sintered at 1400 ${ }^{\circ} \mathrm{C}$ : (a) $\mathrm{x}=0$, (b) $\mathrm{x}=1$, (c) $\mathrm{x}=3$, (d) $\mathrm{x}=10$.

보다 약하기 때문에 균열이 주로 결정립계를 따라 전파하 기 때문으로 판단된다. 많은 연구자들이 $\mathrm{AlN}$ 분말을 스파 크 플라즈마 소결로 연구하였다 $[7,18]$. 초기분말의 크기가 $100 \mathrm{~nm}$ 정도로 미세하여도 $1600{ }^{\circ} \mathrm{C}$ 에서 19 분 가열할 때 입자성장이 일어나서 $\mathrm{AlN}$ 입자의 크기는 $1 \mu \mathrm{m}$ 정도된다고 보고되었다 [7]. Qian 등은 [18] $1800{ }^{\circ} \mathrm{C}$ 에서 15 분 가열 하여 결정립 크기가 $0.5 \mu \mathrm{m}$ 정도의 $\mathrm{AlN}$ 소결체를 제조하 였다. 본 연구와 비교하면 본 연구에서는 짧은 시간에 낮 은 온도에서 나노구조의 $\mathrm{AlN}$ 소결체를 제조하였다. 이것은 본 연구에서는 고 에너지 볼 밀링한 분말을 사용하였기 때 문으로 생각된다.

$\mathrm{AlN}$ 과 $\mathrm{AlN}-\mathrm{BN}$ 복합재료의 경도와 파괴인성은 $20 \mathrm{kgf}$ 하중으로 비커스 경도계로 측정하였다. 경도는 압흔자국의 면적을 계산한 후, 면적분에 하중으로 결정하였고, 파괴인 성은 압흔자국 모서리에서 발생된 균열의 길이를 측정하여 Niihara 식 [17]으로 결정하였다.

그림 8은 압흔자국을 나타낸 것이다. 압흔자국의 면적은 $\mathrm{AlN}$ 에 $\mathrm{BN}$ 을 첨가한 시편에서 작은것을 관찰 할 수 있다. 또한 압흔 자국 모서리에서 균열이 전파되고 있음을 알 수 있다.

$1400{ }^{\circ} \mathrm{C}$ 로 소결한 $\mathrm{AlN}, \mathrm{AlN}-1$ vol\% $\mathrm{BN}, \mathrm{AlN}-3$ $\mathrm{vol} \% \mathrm{BN}, \mathrm{AlN}-10 \mathrm{vol} \% \mathrm{BN}$ 시편의 경도와 파괴 인성은 각각 $943,1455,1147,1110 \mathrm{~kg} / \mathrm{mm}^{2}$ 이고 4, 5.7, 5.5, $5.4 \mathrm{MPa} \cdot \mathrm{m}^{1 / 2}$ 이었다. $\mathrm{AlN}$ 의 경도와 파괴인성은 $\mathrm{BN}$ 첨가 로 동시에 증가하였다. 이 이유는 첫 번째로 $\mathrm{BN}$ 첨가에 의한 $\mathrm{AlN}$ 결정립 크기의 미세화와 두 번째로 $\mathrm{BN}$ 이 균열 전파를 막아주는 효과를 생각할 수 있다. 일반적으로 HallPatch식에 의해 경도는 결정립이 작을수록 증가한다. 본 연 

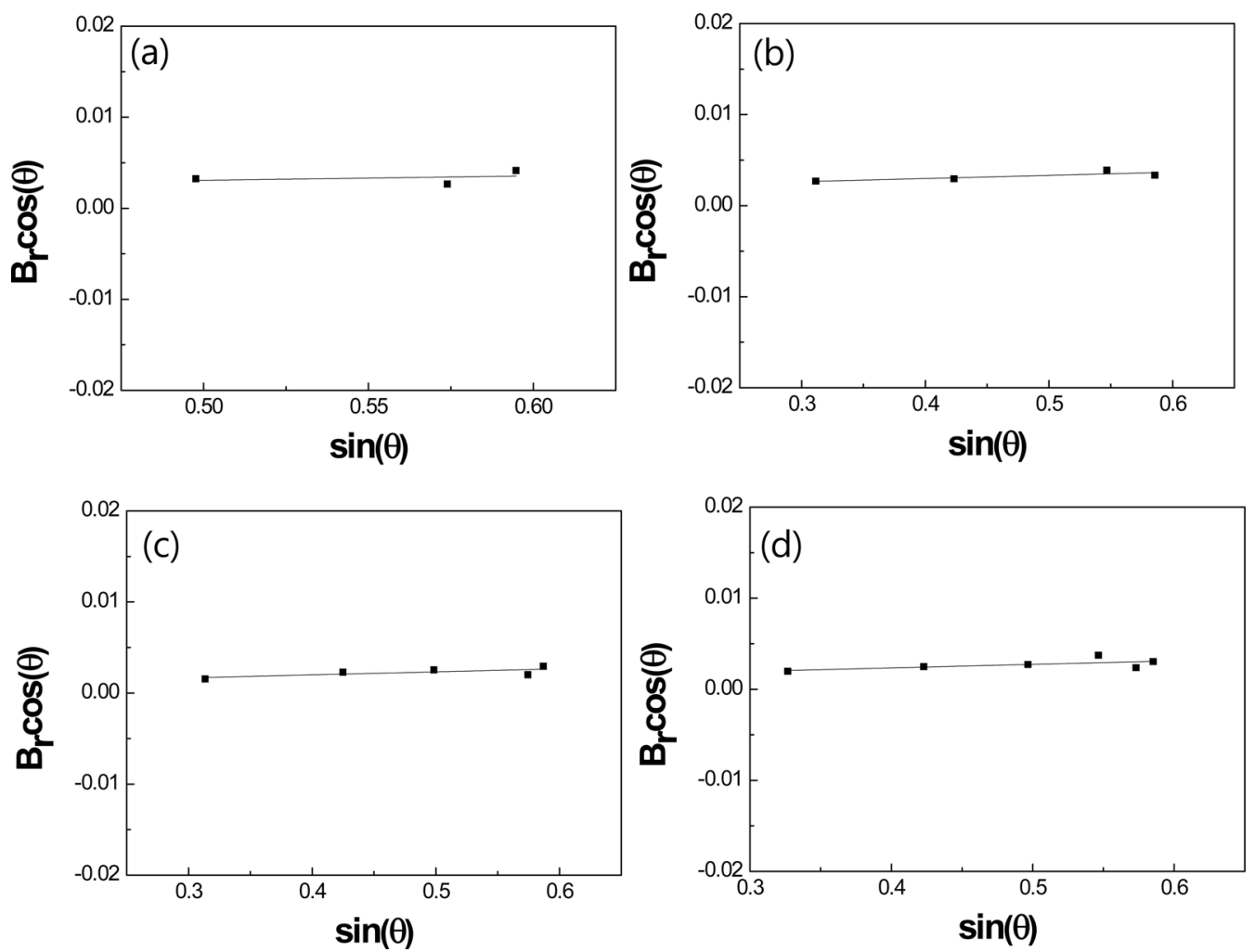

Fig. 6. Plot of $\mathrm{Br}\left(\mathrm{B}_{\text {crystalline }}+\mathrm{B}_{\text {strain }}\right) \cos \theta$ versus $\sin \theta$ for $\mathrm{AlN}$ in $\mathrm{AlN}+\mathrm{x}$ vol\% $\mathrm{BN}$ samples sintered at $1400^{\circ} \mathrm{C}:$ (a) $\mathrm{x}=0$, (b) $\mathrm{x}=1$, (c) $\mathrm{x}=3$, (d) $\mathrm{x}=10$.
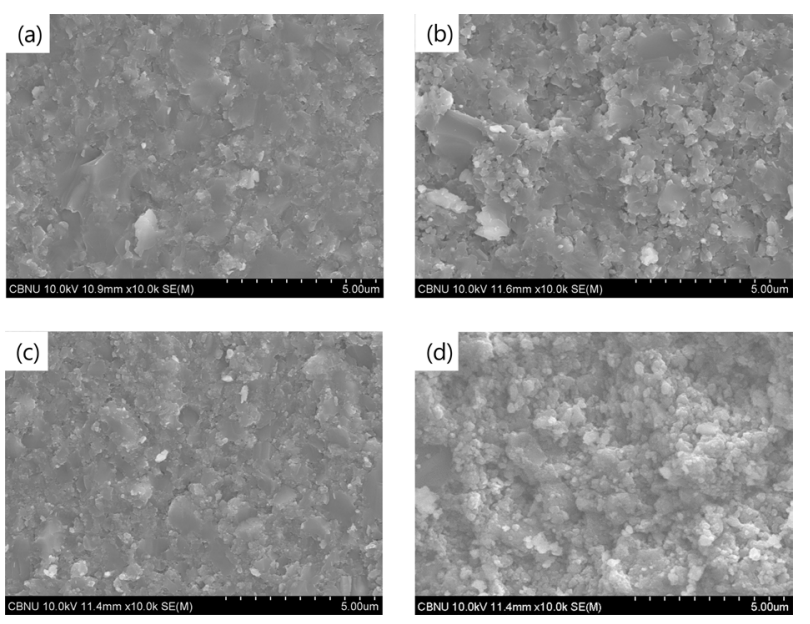

Fig. 7. FE-SEM images of fracture surface of $\mathrm{AlN}+\mathrm{x}$ vol\% $\mathrm{BN}$ samples sintered at $1400{ }^{\circ} \mathrm{C}$ : (a) $\mathrm{x}=0$, (b) $\mathrm{x}=1$, (c) $\mathrm{x}=3$, (d) $\mathrm{x}=10$.

구에서 $\mathrm{AlN}$ 의 결정립 크기는 $\mathrm{BN}$ 첨가로 작아졌다. 세라 믹의 파괴 인성에 미치는 제 2상의 영향에 관해 여러 연 구자들이 연구한 결과, 제 2상이 균열 전파를 억제시키기 때문에 파괴인성을 향상시킨다고 발표하였다 [19].
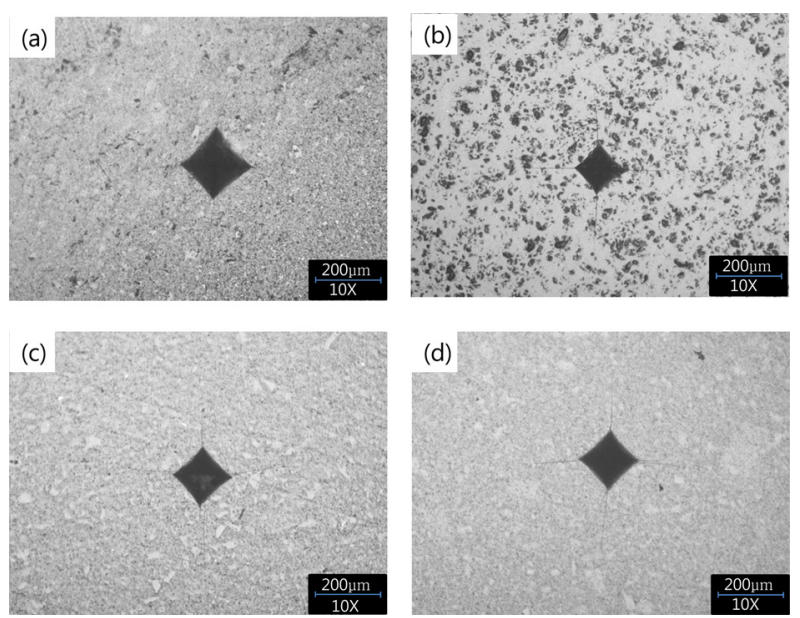

Fig. 8. Vickers hardness indentation of $\mathrm{AlN}+\mathrm{x}$ vol $\% \mathrm{BN}$ samples sintered at $1400^{\circ} \mathrm{C}$ : (a) $\mathrm{x}=0$, (b) $\mathrm{x}=1$, (c) $\mathrm{x}=3$, (d) $\mathrm{x}=10$.

\section{4. 결 론}

$\mathrm{AlN}$ 과 $\mathrm{BN}$ 이 혼합된 분말을 고 에너지 볼밀링으로 나노 분말을 제조하였다. 이들 밀링한 분말에 압력과 펄스 전류 를 가해 2분 이내의 짧은 시간 내에 소결하였다. 소결한 
시편의 미세조직과 기계적 성질을 연구한 결과 아래와 같 은 결론을 얻었다.

1. 고 에너지 볼 밀링으로 나노 분말 $\mathrm{AlN}$ 을 제조하였다.

2. 소결한 시편에서 $\mathrm{AlN}$ 결정립 크기는 $\mathrm{AlN}$ 에 $\mathrm{BN}$ 첨 가량이 증가할수록 작아졌다. 이것은 소결중 $\mathrm{BN}$ 이 $\mathrm{AlN}$ 의 결정립 성장을 억제시키기 때문으로 판단된다.

3. $\mathrm{AlN}$ 과 $\mathrm{AlN}-\mathrm{BN}$ 시편의 파단면에서 균열이 결정립계 를 따라서 전파하는 입계 파괴를 주로 보였다. 이것은 결 정립계 결합이 결정립내 보다 약하기 때문에 결정립계를 따라서 균열이 주로 전파하기 때문으로 생각된다.

4. $\mathrm{AlN}$ 의 경도와 파괴인성은 $\mathrm{BN}$ 첨가로 모두 증가하였 다. 이것은 $\mathrm{AlN}$ 에 $\mathrm{BN}$ 첨가로 $\mathrm{AlN}$ 의 결정립 미세화와 $\mathrm{BN}$ 이 균열전파를 억제시키는 효과에 기인된 것으로 생각 된다.

\section{감사의 글}

본 연구는 산업통상자원부 (MOTIE)와 한국에너지기술 평가원 (KETEP)의 지원을 받아 수행한 연구과제입니다 (No. 20184030202210).

\section{REFERENCES}

1. I.-J. Shon, H. Kwon, and H.-S. Oh, Electron. Mater. Lett. 10, 337 (2014).

2. I.-J. Shon, J.-K. Yoon, and K.-T. Hong, Korean J. Met. Mater. 55, 631 (2017).

3. W. Kim, J.-W. Lim, H.-S. Oh, and I.-J. Shon, Ceram. Int. 40, 2511 (2014).

4. L. Fu, L. H. Cao, and Y. S. Fan, Scripta Mater. 44, 1061
(2001).

5. M. S. El-Eskandarany, J. Alloy. Compd. 305, 225 (2000).

6. Y.-D. Yu, A. M. Hundere, R. Høier, R. E. DuninBorkowski, and M.-A. Einarsrud, J. Eur. Ceram. 22, 247 (2002).

7. R. Terao, J. Tatami, T. Meguro, and K. Komeya, J. Eur. Ceram. 2, 10512 (2002).

8. X. Dua, M. Qinc, A. Raufd, Z. Yuana, B. Yangb, and X. Quc, Mater. Sci. Eng. A 496, 269 (2008).

9. I.-J. Shon, J.-K. Yoon, and K.-T. Hong, Korean J. Met. Mater. 55, 179 (2017).

10. F. Charlot, E. Gaffet, B. Zeghmati, F. Bernard, and J. C. Liepce, Mater. Sci. Eng. A 262, 279 (1999).

11. M. K. Beyer and H. Clausen-Schaumann, Chem. Rev. 105, 2921 (2005).

12. Z. Shen, M. Johnsson, Z. Zhao, and M. Nygren, J. Am. Ceram. Soc. 85, 1921 (2002).

13. J. E. Garay, J. E. Garay, U. Anselmi-Tamburini, and Z. A. Munir, Acta Mater. 51, 4487 (2003).

14. B. Lee, D. Lee, J. H. Lee, H. J. Ryu, and S. H. Hong, Scientific Reports 6, 27609 (2016).

15. I.-J. Shon, Korean J. Met. Mater. 52, 573 (2014).

16. C. Suryanarayana and M. G. Norton, X-ray diffraction: a practical approach, Plenum Press, New York (1998).

17. K. Niihara, R. Morena, and D. P. H. Hasselman, J. Mater. Sci. Lett. 1, 13 (1982).

18. L. Qiao, H. Zhou, and C. Li, Mater. Sci. Eng. B 99, 102 (2003).

19. I.-J. Shon, J.-K. Yoon, and K.-T. Hong, Met. Mater. Int. 24, 130 (2018). 